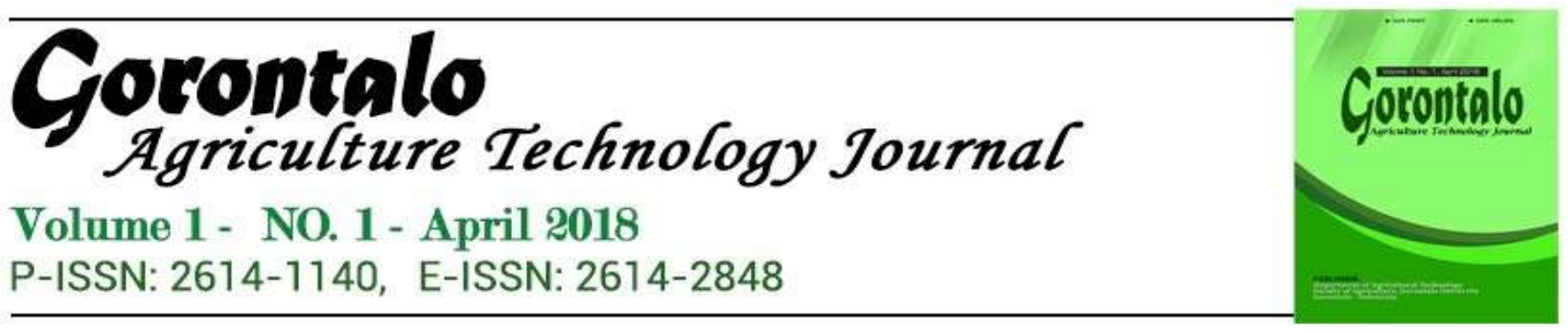

\title{
Analisis Kadar Protein Dan Tingkat Kesukaan Nugget Ikan Gabus Dengan Penambahan Tepung Wortel
}

\author{
Yulianti, Andi Khairun Mutia \\ Program Studi Teknologi Hasil Pertanian, Universitas Gorontalo \\ yuliantibora@gmail.com
}

\begin{abstract}
Snakehead fish one species of freshwater having high protein content. In addition snakehead fish has a lot of meat and white so that it can be processed into products such as nuggets. The addition of carrot flour nuggets in processing aims to increase the nutritional value and reduce the use of a binder such as flour. This research uses the method developed consists of two phases, in the first making carrot flour and the second phase of making nuggets snakehead fish with formulation flour carrot $120 \mathrm{~g}$ , 30g, 40g), tapioca flour (80g, 90g, 70g) and wheat flour (50g, 30g, 40g). Data analysis using a completely randomized design (CRD) with three time test. The results snakehead fish nuggets are a high protein content from 16.03 to $24.7 \%$ and and favored by the panel both in terms of taste, color, aroma and texture.
\end{abstract}

Keyword : snakehead fish, nugget, carrot

\section{PENDAHULUAN}

Ikan Gabus (Ophiocephalus striatus) merupakan jenis ikan yang mudah ditemukan di perairan umum seperti danau dan rawa. Menurut Ulandari et al. (2011), ikan gabus memiliki manfaat antara lain meningkatkan kadar albumin dan daya tahan tubuh, mempercepat proses penyembuhan pasca-operasi dan mempercepat penyembuhan luka dalam atau luka luar.Ikan Gabus khusunya di Provinsi Gorontalo tidak termanfaatkan secara optimal hanya diolah menjadi ikan goreng atau ikan masak sehingga rendahnya minat untuk mengkomsumsinya terutama kalangan anak-anak. Padahal ikan gabus mempunyai kandungan protein yang cukup tinggi yaitu sebesar 25,2\%. Ikan gabus juga mengandung albumin yang tidak dimiliki oleh ikan lainnya seperti ikan lele, ikan gurami, ikan nila, ikan mas dan sebagainya(Yuniarti et al. 2013). Menurut Suprayitno et al., (2008), kandungan asam amino esensial dan asam amino nonesensial pada ikan gabus memiliki kualitas yang jauh lebih baik dari albumin telur. Ikan gabus mempunyai kandungan albumin sebesar $62,24 \mathrm{~g} / \mathrm{kg}$ $(6,22 \%)$. 
Ikan gabus memiliki daging yang banyak dan berwarna putih serta memiliki sedikit tulang sehingga dapat diolah menjadi produk olahan yang lebih modern seperti nugget. Nugget ikan adalah suatu bentuk produk olahan dari daging ikan giling dan diberi bumbu-bumbu serta dicampur dengan bahan pengikat lalu dicetak menjadi bentuk tertentu, dicelupkan ke dalam batter dan breading kemudian digoreng atau disimpan terlebih dahulu dalam ruang pembeku atau freezer sebelum digoreng (Hapsari, 2002).

Bahan pengikat yang biasa digunakan dalam pembuatan nugget adalah tepung terigu dan tepung tapioka. Untuk memperkaya gizi dan mengurangi penggunaan tepung tapioka dan tepung terigu ditambahkan tepung wortel. Dengan adanya penambahan tepung wortel pada nugget maka akan mempengaruhi cita rasa dan kandungan gizi nugget sehingga perlu dilakukan uji tingkat kesukaan terhadap nugget yang dihasilkan.

\section{METODE PENELITIAN}

\subsection{Alat dan Bahan Penelitian}

Alat yang akan digunakan dalam penelitian ini adalah timbangan analitik, pisau, blender, baskom, sendok pengaduk, alat pencetak, dandang dan peralatan penggorengan.

Bahan yang akan digunakan dalam penelitian ini adalah daging ikan gabus, tepung terigu, tepung wortel, tepung roti, telur, minyak goreng, bumbu nugget (bawang putih, bawang merah, merica dan garam).

\subsection{Metode Penelitian}

Penelitian ini dilaksanakan di Laboratorium Teknologi Hasil Pertanian, Universitas Gorontalo dan Balai Pengujian Penanganan Mutu Hasil Perikanan provinsi Gorontalo. Penelitian dilakukan dengan dua tahap, tahap pertama pembuatan tepung wortel dan tahap kedua pembuatan nugget ikan gabus. Data yang diperoleh diolah dengan menggunakan rancangan acak lengkap (RAL) dengan tiga kali ulangan dan dilanjutkan dengan uji beda nyata terkecil (BNT)

\section{a. Tepung Wortel}

Wortel disortasi dan dicuci. Wortel dikupas dan diris tipis dengan diametr 1$5 \mathrm{~mm}$. Dikeringkan pada suhu $70^{\circ} \mathrm{C}$ selama 12 jam. Di haluskan menggunakan blender dan diayak menggunakan ayakan 80 mesh. Tepung wortel siap digunakan.

\section{b. Nugget Ikan Gabus}

Ikan gabus dicuci hingga bersih dan difillet. Daging ikan dihaluskan dan ditambahkan bumbu yang sudah dihaluskan (bawang merah $30 \mathrm{~g}$, bawang putih $20 \mathrm{~g}$, merica $5 \mathrm{~g}$ dan garam $7 \mathrm{~g}$ ), bahan pengikat yang terdiri dari tepung wortel (TW), tepung tapioka (TK) dan tepung terigu (TT) ( TW20 g : TK $80 \mathrm{~g}$ : TT $50 \mathrm{~g}$, TW $30 \mathrm{~g}$ : TK $90 \mathrm{~g}$ : TT $30 \mathrm{~g}$, TW $40 \mathrm{~g}$ : TK $70 \mathrm{~g}$ : TT $40 \mathrm{~g})$ dan ditambahkan air $50 \mathrm{ml}$. Diaduk hingga homogen. Adonan dipipihkan dan dikukus selama 20 menit. Didinginkan dan dibentuk persegi panjang (Analisa protein dan lemak). Dibaluri telur dan tepung roti. Nugget digoreng 
didalam minyak panas dengan suhu $\left(170^{\circ} \mathrm{C}\right)$ ditiriskan dan nugget ikan gabus siap diuji organoleptic(tingkat kesukaan).

\subsection{Parameter Pengamatan}

\section{a. Kadar Protein}

Ditimbang kurang lebih 0,5 gr sampel. Dimasukkan kedalam labu khjedhal $100 \mathrm{ml}$. Ditambahkan kurang lebih 1 gr campuran selenium dan $10 \mathrm{ml}$ $\mathrm{H}_{2} \mathrm{SO}_{4}$ pekat. Labu khjedhal bersama isinya digoyangkan sampai semua sampel terbasahi dengan $\mathrm{H}_{2} \mathrm{SO}_{4}$. Disetruksi dalam lemari asam sampai jernih, setelah dingin, dituang kedalam labu ukur $100 \mathrm{ml}$ dan dibilas dengan air suling kemudian ditambahkan dengan air suling sampai pada tanda garis isiapkan labu penampung yang terdiri dari $10 \mathrm{ml} \mathrm{H}_{3} \mathrm{BO}_{3} 2 \%$ ditambahkan dengan 4 tetes larutan indikator campuran dalam erlenmeyer $100 \mathrm{ml}$. Pipet $5 \mathrm{ml}$ larutan $\mathrm{NaOH} 30 \%$ dari air suling kemudian disuling hingga volume penampung menjadi lebih kurang $50 \mathrm{ml}$. Dibilas ujung penyuling dengan air suling kemudian penampung bersama isinya dititrasi dengan larutan $\mathrm{HCL}$ atau $\mathrm{H}_{2} \mathrm{SO}_{4}$ 0,0222 N. Dihitung dengan menggunakan rumus sebagai berikut:

$$
\% \text { protein }=\frac{\text { V1 } \times \text { Normalitas } H 2 S O 4 \times 6,25 \times p}{\text { gram bahan }} \times 100 \%
$$

Keterangan :

V1 : Volume titrasi bahan

$\mathrm{N} \quad$ :Normalitas larutan $\mathrm{HCl}$ atau $\mathrm{H}_{2} \mathrm{SO}_{4} 0,02 \mathrm{~N}$

P : : Faktor pengenceran 100/5

\section{b. Uji Organoleptik (Tingkat Kesukaan)}

Penilaian organoleptik dilakukan terhadap warna, rasa, aroma dan tekstur pada produk nugget ikan gabus. Metode yang digunakan adalah metode hedonik (kesukaan). Pengujian organoleptik dilakukan berdasarkan uji hedonik dengan panelis sebanyak 15 orang dan dilakukan oleh mahasiswa Teknologi Hail Pertanian. Panelis diminta untuk memberikan penilaian berdasarkan tingkat kesukaannya dengan skor digunakan adalah 1 : sangat tidak suka, 2 : tidak suka, 3 : agak suka, 4 : suka, 5 : sangat suka.

\section{HASIL DAN PEMBAHASAN}

\section{a. Kadar Protein}

Pengolahan ikan gabus menjadi nugget yang diformulasi dengan tepung wortel, tepung tapioka dan tepung terigu memiliki kadar protein yang berkisar antara 16,03-24,7\%. Kadar protein yang dihasilkan sudah sesuai dengan SNI yang ditetapkan Departemen Perindustrian (2002) yaitu standar kadar protein nugget minimal $12 \%$. 


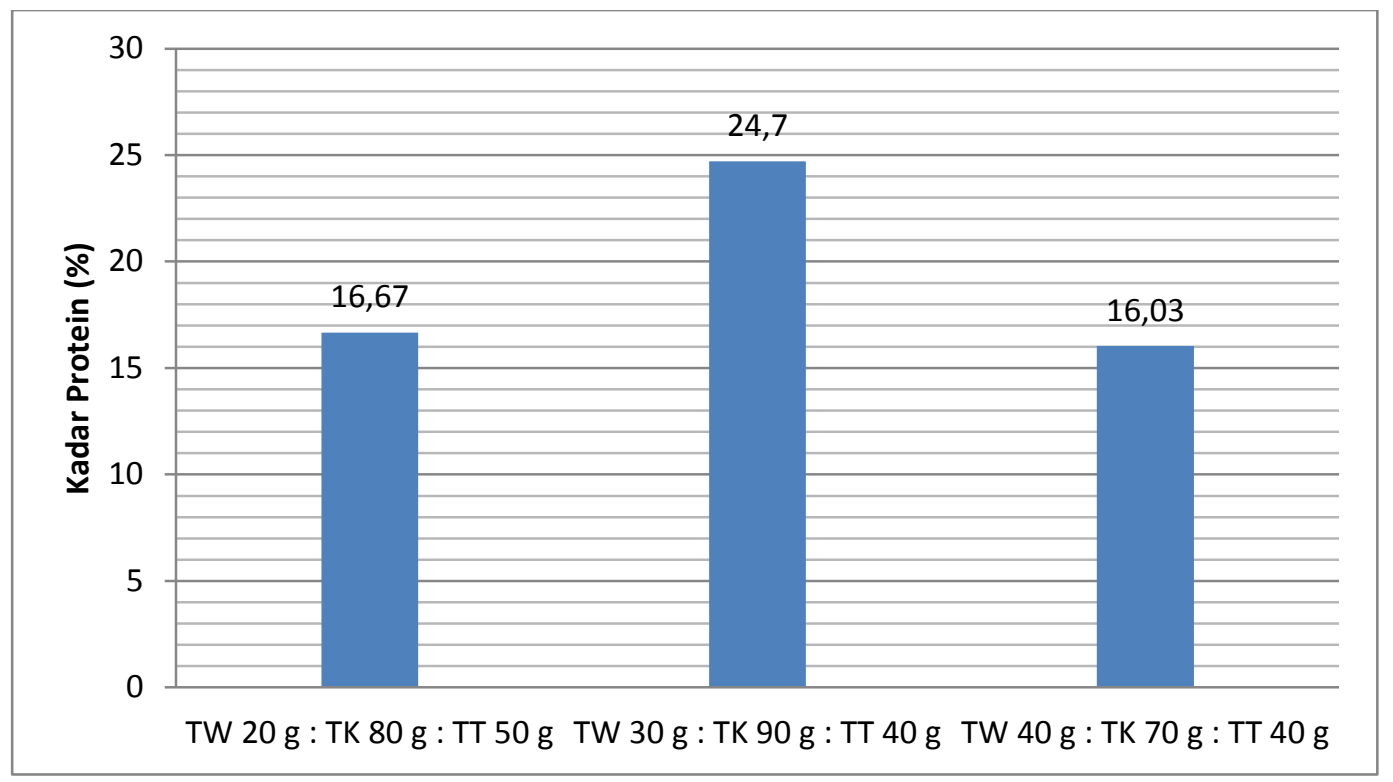

Gambar 1. Kadar Protein Nugget Ikan Gabus

Kadar protein nugget ikan gabus dengan bahan pengikat yang terdiri dari tepung wortel $30 \mathrm{~g}$ : tepung tapioka $90 \mathrm{~g}$ : tepung terigu $30 \mathrm{~g}$ sebesar $24,7 \%$. Sedangkan kadar protein yang terendah terdapat pada perlakuan dengan perbandingan tepung wortel $40 \mathrm{~g}$ : tepung tapioka $70 \mathrm{~g}$ : tepung terigu $40 \mathrm{~g}$ sebesar 16,03\%. Kadar protein ikan gabus yang semula 25,2 \% mengalami proses penurunan setelah diolah menjadi nugget. Hal ini disebabkan karena pada proses pengolahan protein akan terdenaturasi dan berekasi dengan gula pereduksi membentuk reaksi maillard. Reaksi maillard terjadi antara gugus aldehid dari gula pereduksi dengan gugus amina terutama epsilon-amino-lisin dan alfa amino asam amino N-terminal. Reaksi ini banyak terjadi pemanasan daging terutama apabila kontak dengan bahan nabati (Ishak, 2012).

\section{b. Uji Organoleptik}

Uji organelptik merupakan uji yang bertujuan untuk mengetahui daya terima atau tingkat kesukaan suatu produk pangan yang dianggap baru dan asing bagi masyarakat yang diwakili oleh panelis. Uji ini meliputi tingkat kesukaan terhadap rasa, aroma, warna, dan tektur dari produk yang dihasilkan.

Tabel 1. Hasil Uji Organoleptik (Tingkat Kesukaan) Nugget Ikan Gabus

\begin{tabular}{|l|c|c|c|c|}
\hline \multicolumn{2}{|c|}{ Perlakuan } & \multicolumn{4}{|c|}{ Parameter } \\
\cline { 2 - 6 } & Rasa & Aroma & Warna & Tekstur \\
\hline $\begin{array}{l}\text { Tepung Wortel 20g : Tepung } \\
\text { Tapioka 80g: Tepung Terigu 50g }\end{array}$ & 3,76 & 3,96 & 3,53 & 3,66 \\
\hline $\begin{array}{l}\text { Tepung Wortel 30g : Tepung } \\
\text { Tapioka 90g: Tepung Terigu 30 g, }\end{array}$ & 3,76 & 3,50 & 3,56 & 3,66 \\
\hline $\begin{array}{l}\text { Tepung Wortel 40g : Tepung } \\
\text { Tapioka 70g: Tepung Terigu 40g }\end{array}$ & 3,40 & 3,60 & 3,36 & 3,33 \\
\hline
\end{tabular}


Rasa makanan yang kita kenal sehari-hari sebenarnya bukanlah satu tanggapan, melainkan campuran dari tanggapan cicip, bau dan trigeminal yang diramu oleh kesan-kesan lain seperti penglihatan, sentuhan dan pendengaran. Jadi, jika kita menikmati atau merasakan makanan sebenarnya kenikmatan tersebut diwujudkan bersama-sama oleh kelima indra. Berdasarkan tabel 1 semakin tinggi kosentrasi tepung wortel yang digunakan tingkat kesukaan terhadap rasa nugget ikan gabus semakin menurun.

Aroma atau bau merupakan sesuatu yang dapat diamati dengan indra pembau. Aroma berasal dari senyawa volatile yang dapat larut dalam air dan larut dalam lemak. Aroma nugget ikan gabus yang dihasilkan (Tabel 1) menujukkan bahwa semakin sedikit tepung wortel yang digunakan semakin disukai aroma nugget yang dihasilkan. Hal ini disebabkan karena konsentrasi tepung wortel yang tinggi akan menutupi aroma ikan gabus.

Warna adalah parameter pertama untuk menentukan penerimaan suatu produk makanan. Warna yang menarik akan menjadi selera konsumen untuk mengkonsumsi makanan tersebut. Suatu bahan yang bernilai gizi, enak dan teksturnya baik tidak awan dimakan apabila warna yang tidak sedap dipandang atau memberi kesan menyimpan dari warna yang seharusnya. Baik tidaknya cara pencampuran atau cara pengolahan dapat ditandai dengan adanya warna yang seragam (Winarno, 2004). Warna dapat diamati dari jauh dengan menggunakan indra penglihatan. Tabel 1 menunjukkan bahwa perbedaan konsentrasi tepung yang digunakan tidak berpengaruh secara signifikan terhadap tingkat kesukaan warna dari nugget yang dihasilkan. Nugget ikan gabus yang dihasilkan di sukai oleh panelis. Semakin tinggi konsentrasi tepung wortel yang digunakan warna nugget yang dihasilkan semakin gelap disebabkan dari warna orange dari tepung wortel ditambah adanya rekasi maillard yang terjadi akibat penggorengan.

Tekstur merupakan sensasi tekanan yang dapat diamati dengan mulut (pada waktu digigit, dikunyah, dan ditelan) ataupun perabaan dengan jari. Jumlah pati yang besar menyebabkan tekstur menjadi lebih padat dan cenderung keras (Surawan, 2007). Kandungan pati pada nugget ikan gabus berasal dari tepung tapioka dan tepung terigu semakin tinggi konsentrasi tepung terigu dan tepung tapioka yang digunakan tekstur nugget yang dihasilkan padat dan disukai oleh panelis.

\section{KESIMPULAN}

Nugget ikan gabus yang bahan pengikatnya terdiri dari tepung wortel, tepung tapioka, dan tepung terigu memiliki kadar protein yang tinggi $16,03-$ $24,7 \%$ dan disukai oleh panelis baik dari segi rasa, warna, aroma dan tektur.

\section{REFERENSI}

Departemen Perindustrian RI. 2002. Syarat Mutu Nugget SNI 01-6683-2002. Jakarta. Departemen Perindustrian RI.

Ishak., Elly. 2012. Ilmu dan Teknologi Pangan. Universitas Hassanudin, Makassar. 
Hapsari RD. 2002. Pengolahan Daging Ikan Patin (Pangasius pangasius) Menjadi Bakso, Sosis, Nugget dan Pemanfaatan Limbahnya menjadi Tepung Ikan. Skripsi. Fakultas Teknologi Pertanian. Institut Pertanian Bogor. Bogor.

Suprapti, L., 2008. Teknologi Pengolahan Pangan : Produk Olahan Ikan. Penerbit Kanisius, Yogyakarta.

Suprayitno , E., A. Chamidah dan Carvallo. 2008. Albumin Ikan Gabus (Ophiocephalus striatus) Sebagai Makanan Fungsional Mengatasi Permasalahan Gizi Masa Depan. Pidato Pengukuhan Jabatan Guru Besar dalam Ilmu Biokimia Ikan. Rapat Terbuka Senat. Fakultas Perikanan Universitas Brawijaya. Malang.

Surawan, FED. 2007. Penggunaan Tepung Terigu, Tepung Beras, Tepung

Tapioka Dan Tepung Maizena Terhadap Tekstur Dan Sifat Sensoris Fish Nugget Ikan Tuna. Jurnal Sain Peternakan Indonesia 2 (2): 78-84.

Ulandari, A.; D. Kurniawan dan A.S. Putri, 2011. Potensi Protein Ikan Gabus dalam Mencegah Kwashiorkor pada Balita di Provinsi Jambi. Universitas Jambi. Jambi. Hal. 6.

Winarno FG. 2004. Kimia Pangan Dan Gizi. PT Gramedia Pustaka Utama, Jakarta.

Yuniarti, D.W., Titik, D.S., dan Eddy, S., 2013. Pengaruh Suhu Pengeringan Vakum Terhadap Kualitas Serbuk Albumin Ikan Gabus (Ophiocephalus striatus). THPi Student Journal, VOL. 1 NO. 1 pp 1-9. 